UDC 663.81

IRSTI 65.51 .29

https://doi.org/10.48184/2304-568X-2020-4-32-37

\title{
INFLUENCE OF HEAT TREATMENT ON THE AMINO ACID COMPOSITION OF GRAPE JUICES DIRECT EXTRACTION
}

\author{
${ }^{1}$ A.K. KEKIBAYEVA, ${ }^{2}$ A. KONYS, ${ }^{1}$ G.I. BAYGAZIEVA \\ ( ${ }^{1}$ Almaty Technological University, Almaty, Kazakhstan, \\ ${ }^{2}$ Kazakh National Agrarian University, Kazakhstan) \\ E-mail: anara_06061983@mail.ru
}

Currently, the development of technology for functional beverages based on direct-pressed grape juice is a particularly important and urgent task due to the presence of a diverse and affordable raw material base in the South of Kazakhstan. In view of the fact that high temperatures applied for a short time do not have a profound negative impact on the quality of juice, the assessment of heat treatment as a key technological stage that affects the change in the composition of free amino acids in experimental samples of straight-pressed wine juices was carried out. Taking into account the totality of data from the organoleptic and chemical analysis of experimental samples, for the production of juices with a high level of biological value, we recommended the Sensation and Husain red grape varieties with a high set of amino acids after the pasteurization process: $1504.5 \mathrm{mg} / \mathrm{dm}^{3}$ and $1288.8 \mathrm{mg} / \mathrm{dm}^{3}$, respectively.

Key words: non-alcoholic drinks, direct extracted juices, amino acids, grape, pasteurization.

\section{ТІКЕЛЕЙ СЫҒЫЛҒАН ЖҮЗІМ ШЫРЫНДАРЫНЫН АМИН ҚЫШҚЫЛДЫҚ КҰРАМЫНА ЖЫЛУЛЫҚ ӨНДЕУДІН ӘСЕР}

\author{
${ }^{1}$ А.К. КЕКИБАЕВА, ${ }^{2}$ A. ҚОНЫС, ${ }^{1}$ Г.И. БАЙГАЗИЕВА
}

\author{
( 1 Алматы технологиялық университеті, Алматы, Қазақстан, \\ ${ }^{2}$ Қазақ ұлттық аграрлық университеті, Алматы, Қазақстан) \\ E-mail: anara_06061983@mail.ru
}

Қазіргі уақытта тікелей сызылzан жүзім шырыны негізінде функционалдық сусындар технологиясын әзірлеу Қазақстанның оңтүстігінде әртүрлі және қолжсетімді иикізат базасының болуына байланысты ерекше маңызды және өзекті міндет болып табылады. Қысқа уақыт ішінде қолданылатын жсогары температура шырынның сапасына терең теріс әсер етпейтіндіктен, тікелей сывылган жүзім шырындардың зерттеу үлгілеріндегі бос аминқышқылдарының құрамының өзгеруіне әсер ететін негізгі технологиялық кезең ретінде жылумен өңдеуге багалау жүргізілді. Зерттеу үлгілердің органолептикалық және химиялық талдауы мәліметтерінің жиынтыгын ескере отырып, биологиялық құндылыгы жсогары шырындар өндіру үшін залалсыздандыру процесінен кейін амин қышқылдарының жсогары жсиынтыгы бар

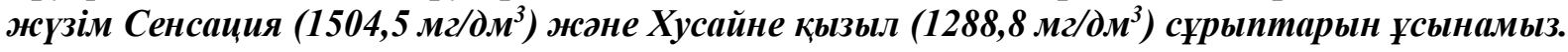

Негізгі сөздер: алкогольсіз сусындар, тікелей сығылған шырындар, амин қышқылдары, жүзім, залалсыздандыру.

\section{ВЛИЯНИЕ ТЕПЛОВОЙ ОБРАБОТКИ НА АМИНОКИСЛОТНЫЙ СОСТАВ ВИНОГРАДНЫХ СОКОВ ПРЯМОГО ОТЖИМА}

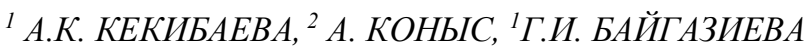

\footnotetext{
( ${ }^{1}$ Алматинский технологический университет, Алматы, Казахстан, ${ }^{2}$ Казахский Национальный аграрный университет, Алматы, Казахстан) E-mail: anara_06061983@mail.ru
} 
В настоящее время разработка технологии функциональных напитков на основе виноградного сока прямого отжсима является особенно важсной и актуальной задачей в связи с наличием разнообразной и доступной сырьевой базы на Юге Казахстана. Ввиду того что высокие температуры, применяемые в течение короткого времени, не оказывают глубоких негативных воздействий на качество сока проведена оценка тепловой обработки, как ключевого технологического этапа, влияющего на изменение состава свободных аминокислот в экспериментальных образцах виногрдных соков прямого отжнма. Учитывая совокупность данных органолептического и химического анализа экспериментальных образцов, для производства соков с высоким уровнем биологической ценности нами рекомендованы сорта винограда "Сенсация" и "Хусайне красный" с высоким набором аминокислот после процесса пастери-

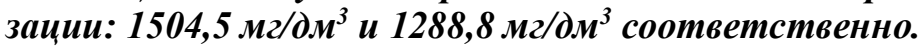

Ключевые слова: безалкогольные напитки, соки прямого отжима, аминокислоты, виноград, пастеризация.

\section{Introduction}

Currently, in Kazakhstan along with other countries there is a steady, increased interest of consumers in food products rich in natural biologically active substances, including plant origin. Today consumers prefer natural products, and also have a positive attitude to functional products.

Functional food products are special food products intended for systematic use in the diet of all age groups of a healthy population, which have scientifically proven and proven properties, reduce the risk of developing diseases related to nutrition, and preserve and improve health due to the presence of functional food ingredients in their composition [1].

All functional food products contain ingredients that determine their directed action: dietary fibers (soluble and insoluble), vitamins, minerals, polyunsaturated fats, antioxidants, oligosaccharides (as a substrate for beneficial bacteria), as well as a group including trace elements, bifidobacteria, etc.

Medicine in many countries, as well as in Kazakhstan, defines a functional soft drink as an acceptable form of food used for an arbitrary number of consumers and used to enrich the human body with biologically active substances [2].

Functional non-alcoholic drinks can have a preventive effect on the human body or a therapeutic and complex result, arouse positive emotions when apperception of flavor and taste. Directly, they can be safe under the following conditions: if the composition contains a natural base from non-traditional raw materials; if they are produced using natural flavor components, if they contain biologically active substances in strict accordance with their functional purpose, which is especially important when creating target products [3].
Fruit and vegetable juices, which are the main component of non-alcoholic drinks, contain vitamin $\mathrm{C}$, beta-carotene, a complex of $\mathrm{B}$ vitamins, and the introduction of new ingredients is not very difficult [4].

Enriched with dietary fiber and trace elements, beverages can be used to prevent cardiovascular, gastrointestinal diseases, cancer and other diseases, as well as to eliminate various types of intoxication. Grapes contain a large number of biologically valuable components and nutrients: sugars (glucose and fructose), organic acids, tannins and minerals, vitamins and vital amino acids. However, the presence of a large number of physiologically significant substances and elements directly in the grape berry does not mean their sufficient content in the products of its processing, including in direct-pressed juices, which are valuable nutritional and dietary components of nutrition. During the production of these juices obtained by pressing, fat - soluble vitamins, part of macro-and microelements, and amino acids are lost in the pomace and precipitation. In addition, the loss of valuable components also occurs as a result of technological operations for clarification and stabilization of products. It should also be noted that grape juice lacks a number of trace elements, including such an important component as iodine, which is allocated to a special group of so-called essential trace elements.

One of the ways to replenish these substances and increase the nutritional value of juices can be the development of a series of recipes for functional drinks based on grape juice and plant extracts. Preparation of such drinks will allow you to balance the composition of grape juice on the content of biologically active substances, saturate it with scarce macro-and micronutrients [5]. 
The development of technology for functional drinks based on grape juice using plant extracts is a particularly important and urgent task due to the presence of a diverse and affordable raw material base in the South of Kazakhstan, as well as the high concentration of fruit processing plants in this region equipped with modern high-performance equipment.

\section{Materials and research methods}

As objects of research were used red and white table grape varieties. Among them, Husain red, Husain white, Sensation Bull eye and Tayfi white (table 1).

The research was carried out in the educational laboratory "Technology of fermentation and winemaking" of the Department "Technology of bakeries and processing productions" of the Almaty Technological university.

Table 1 - Characteristics of red and white grape varieties

\begin{tabular}{|c|c|c|c|c|}
\hline Variety & Ripening period & The weight of bunches, $\mathrm{g}$ & The size of berries & Yield, c/g \\
\hline Husain red & late & 345 & Large & $150-200$ \\
\hline Husain white & middle & 300 & Large & $110-115$ \\
\hline Sensation & late & 800 & Large & $150-200$ \\
\hline Tayfi white & late & 650 & Large & $110-115$ \\
\hline
\end{tabular}

The physical and chemical composition is determined according to the established methods: the dry matter content is refractometrically, the density is hydrometrically at $20^{\circ} \mathrm{C}[6]$.

Determination of the amino acid composition was performed on the AAA-835 amino acid analyzer (Hitachi, Japan) by liquid chromatography on a Biosil-400 column after preliminary hydrolysis of $6 \mathrm{~N} \mathrm{HCl}$ samples for 24 hours at a temperature of $105{ }^{\circ} \mathrm{C}$ and evaporation on a rotary evaporator at a water bath temperature of no more than $60^{\circ} \mathrm{C}[7]$.

\section{Results and their discussion}

To establish the possibility of obtaining high - quality grape juices from table grapes and to identify the influence of the grape variety on the quality of direct - pressed juices, red grape varieties, Husain red, Sensation, Bull eye and white varieties, Husain white, Taifi white were selected.

All obtained samples of direct-pressed juices from the studied grape varieties met the requirements of the standards (table 2).

Table 2 - Indicators of the physical and chemical composition of the initial samples of work

\begin{tabular}{|c|c|c|c|c|}
\hline Indicator & $\begin{array}{c}\text { Husain } \\
\text { white }\end{array}$ & $\begin{array}{c}\text { Husain } \\
\text { red }\end{array}$ & Sensation & $\begin{array}{c}\text { Tayfi } \\
\text { white }\end{array}$ \\
\hline $\begin{array}{c}\text { Name of the indicator of mass } \\
\text { concentration of sugars, g / 100 cm }\end{array}$ & 21,10 & 20,00 & 18,50 & 21,15 \\
\hline $\begin{array}{c}\text { Mass fraction of titrated acids in terms } \\
\text { of tartaric acid, g / dm }\end{array}$ & 4,15 & 4,53 & 4,82 & 4,14 \\
\hline $\mathrm{pH}$ & 3,46 & 3,30 & 3,32 & 3,44 \\
\hline
\end{tabular}

The samples obtained differed in the number of titrated acids, sugars, and solids. It should be noted that the nutritional value of grape juices is determined primarily by the presence of natural sugars (glucose, fructose, sucrose), which are quickly absorbed and oxidized in the body, being easily digestible sources of energy.

The sugar content of the obtained samples of direct-pressed juices ranged from 18.60 (Sensation) to $21.20 \mathrm{~g} / 100 \mathrm{~cm}^{3}$ (Husain white). Another important component of juices are organic acids that contribute to the digestive process. Their content ranged from 4.15 (Tayfi white) to $4.83 \mathrm{~g} / \mathrm{dm}^{3}$ (Sensation). Acids of grape juices are mainly represented by wine and apple, as well as citric, amber, acetic and lactic acids in smaller quantities.

Long-term heat treatment, aimed at suppressing the activity of microorganisms and inactivating the enzymes of grape raw materials, has a negative impact on the quality of products and their biological value. However, it is known that high temperatures applied for a short time do not have profound negative effects on the quality of the juice. In view of this, the evaluation of the 
adopted variant of heat treatment as a key technological stage affecting the change in the composition of free amino acids in experimental samples of juices was carried out.

The grape synthesizes a number of nitrogenous substances that are characteristic of any plant organism. A significant amount of nitrogenous substances in grape juice are represented by peptides that, under the influence of the natural acidity of the juice, are hydrolyzed to amino acids under the influence of proteolytic enzymes [8]. In the analyzed juices from the studied grape varieties, 14 amino acids were identified, of which 7 are essential (table 3).

Table 3 - The effect of pasteurization on changes in the amino acid composition of direct-pressed grape juice

\begin{tabular}{|c|c|c|c|c|c|c|c|c|c|}
\hline \multirow{2}{*}{\multicolumn{2}{|c|}{$\begin{array}{c}\text { Amino acids, } \\
\mathrm{mg} / \mathrm{dm}^{3}\end{array}$}} & \multicolumn{2}{|c|}{ Tayfi white } & \multicolumn{2}{|c|}{ Husain red } & \multicolumn{2}{|c|}{ Sensation } & \multicolumn{2}{|c|}{ Husain white } \\
\hline & & before & after & before & after & before & after & before & after \\
\hline \multirow{7}{*}{ 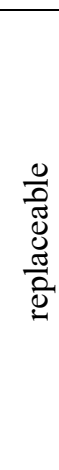 } & Arginine & 74,7 & 38,1 & 60,3 & 51,2 & 34,5 & 31,8 & 48,8 & 48,9 \\
\hline & Histidine & 60,7 & 10,3 & 43,4 & 14,0 & 30,9 & 8,5 & 16,5 & 12,8 \\
\hline & \begin{tabular}{|l|} 
Proline \\
\end{tabular} & 1087 & 236,8 & 1381 & 831,2 & 3385 & 1380 & 1085 & 324 \\
\hline & $\begin{array}{l}\text { Serine } \\
\end{array}$ & 89,7 & 16,2 & 156,7 & 88,2 & 60,5 & 27,3 & 87,3 & 26,5 \\
\hline & $\alpha$-alanine & 65,5 & 9,5 & 194,4 & not found & 53,0 & 12,1 & 66,8 & 9,2 \\
\hline & \begin{tabular}{|l|} 
Tyrosine \\
\end{tabular} & 73,4 & $\begin{array}{c}\text { not } \\
\text { found }\end{array}$ & 60,5 & 28,1 & 35,0 & $\begin{array}{c}\text { not } \\
\text { found }\end{array}$ & $\begin{array}{c}\text { not } \\
\text { found }\end{array}$ & $\begin{array}{c}\text { not } \\
\text { found }\end{array}$ \\
\hline & Glycine & $\begin{array}{c}\text { not } \\
\text { found }\end{array}$ & $\begin{array}{c}\text { not } \\
\text { found }\end{array}$ & $\begin{array}{c}\text { not } \\
\text { found }\end{array}$ & not found & 2,4 & $\begin{array}{c}\text { not } \\
\text { found }\end{array}$ & $\begin{array}{c}\text { not } \\
\text { found }\end{array}$ & $\begin{array}{c}\text { not } \\
\text { found }\end{array}$ \\
\hline \multirow{7}{*}{ 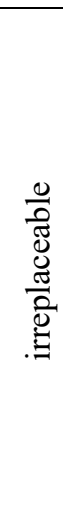 } & $\beta$-phenylalanine & 21,2 & $\begin{array}{c}\text { not } \\
\text { found }\end{array}$ & 10,8 & 9,0 & 10,7 & $\begin{array}{c}\text { not } \\
\text { found }\end{array}$ & 9,0 & 8,9 \\
\hline & \begin{tabular}{|l} 
Leytsin \\
\end{tabular} & 50,7 & 8,9 & 36,1 & 4,7 & 37,1 & 11,6 & 24,6 & 10,3 \\
\hline & Methianine & 74,3 & 25,3 & 323,6 & 130,2 & 117,2 & 49,2 & 111,9 & 32,5 \\
\hline & Protector & 37,1 & 7,7 & 157,1 & 16,5 & 28,6 & 28,7 & 23,5 & 6,1 \\
\hline & Treanin & 240,6 & 36,2 & 233,1 & 68,0 & 154,5 & 45,5 & 99,8 & 30,1 \\
\hline & \begin{tabular}{|l|} 
Tryptophan \\
\end{tabular} & 49,8 & $\begin{array}{c}\text { not } \\
\text { found }\end{array}$ & 45,6 & 44,7 & 41,7 & 8,7 & 33,1 & 3,9 \\
\hline & Lysine & $\begin{array}{c}\text { not } \\
\text { found }\end{array}$ & $\begin{array}{c}\text { not } \\
\text { found }\end{array}$ & $\begin{array}{c}\text { not } \\
\text { found }\end{array}$ & not found & 6,0 & $\begin{array}{c}\text { not } \\
\text { found }\end{array}$ & $\begin{array}{c}\text { not } \\
\text { found }\end{array}$ & $\begin{array}{c}\text { not } \\
\text { found }\end{array}$ \\
\hline & Total & $\frac{n}{\tilde{a}}$ & $\bar{m}$ & 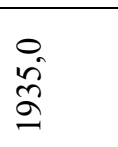 & $\begin{array}{l}\infty \\
\infty \\
\stackrel{\infty}{\simeq} \\
=\end{array}$ & ڤे & $\begin{array}{l}+ \\
\stackrel{D}{n} \\
\end{array}$ & $\frac{\nabla_{n}}{\sigma}$ & $\stackrel{m}{\tilde{n}}$ \\
\hline
\end{tabular}

The highest content of free amino acids was recorded in the must varieties Sensation and Husain red. The lowest content was recorded in the must of Taifi white varieties. At the same time, half of the total amount was Proline, as in wine products. The individual composition of amino acids in the studied juices is determined by the grape variety and the applied agricultural techniques. As a result of short-term heat treatment $\left(82-85^{\circ} \mathrm{C}\right.$ for $2-2.5$ minutes $)$, a significant (more than 2 times) decrease in the total concentration of amino acids in all analyzed juice samples was found (figure 1). This factor indicates that heat treatment intensifies chemical processes involving amino acids. 


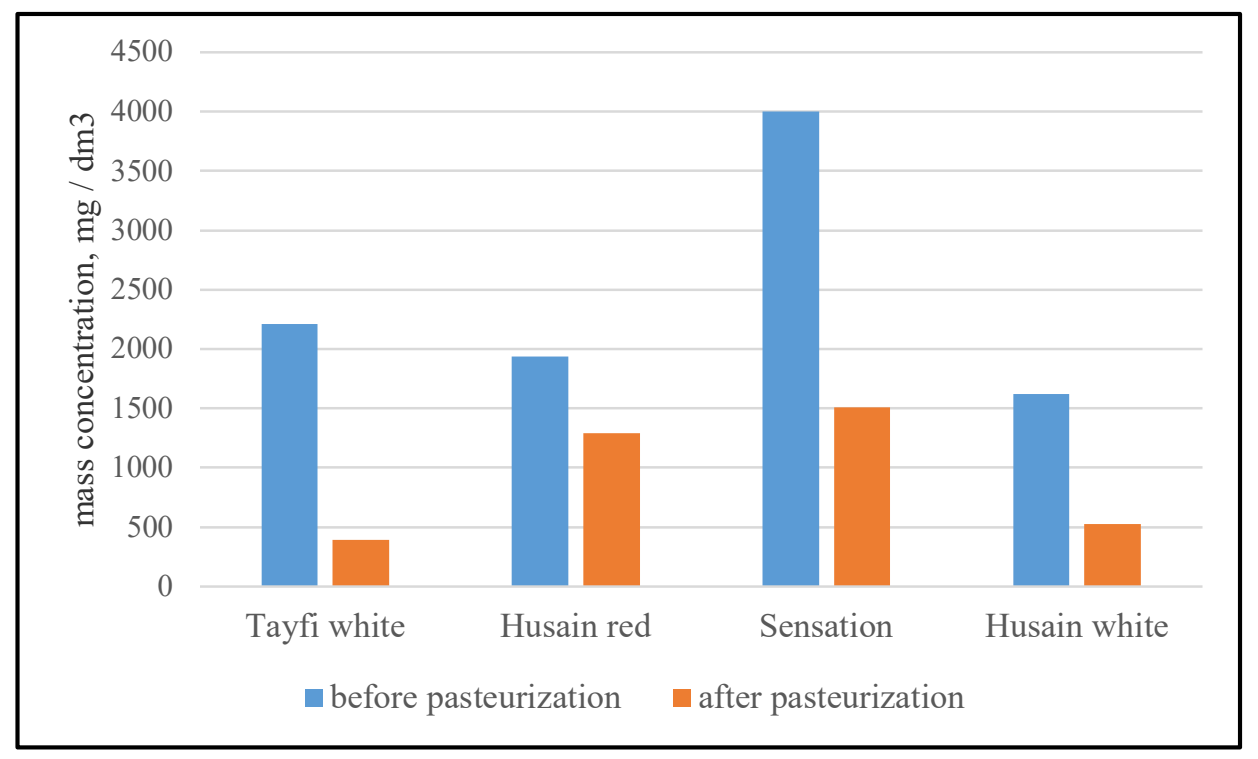

Figure 1. The effect of pasteurization on the change in the amino acid composition of juices of direct extraction from the grape varieties

In the case of Sensation grape juice, the total amino acid content decreased by $63 \%$ after heat treatment. It was found that due to pasteurization, no amino acids such as (3-phenylalanine, tyrosine, lysine, and glycine) were found in the juice. The concentration of arginine was not significantly affected by pasteurization, which indicates a certain degree of resistance of this amino acid to high temperatures. A similar pattern was observed for this amino acid in other juice variants. In the juice of grapes from the Sensation variety, there was a significant decrease in the content of amino acids such as histidine, tryptophan and a-alanine - by 73$79 \%$. The content of other amino acids decreased by an average of $60 \%$. It should be noted that the content of essential amino acids in the studied juice samples after pasteurization was at the level of 63.3 to $275.1 \mathrm{mg} / \mathrm{dm}^{3}$ (figure 2). At the same time, the lowest content of essential amino acids was found in the version of the juice from the Husain white variety.

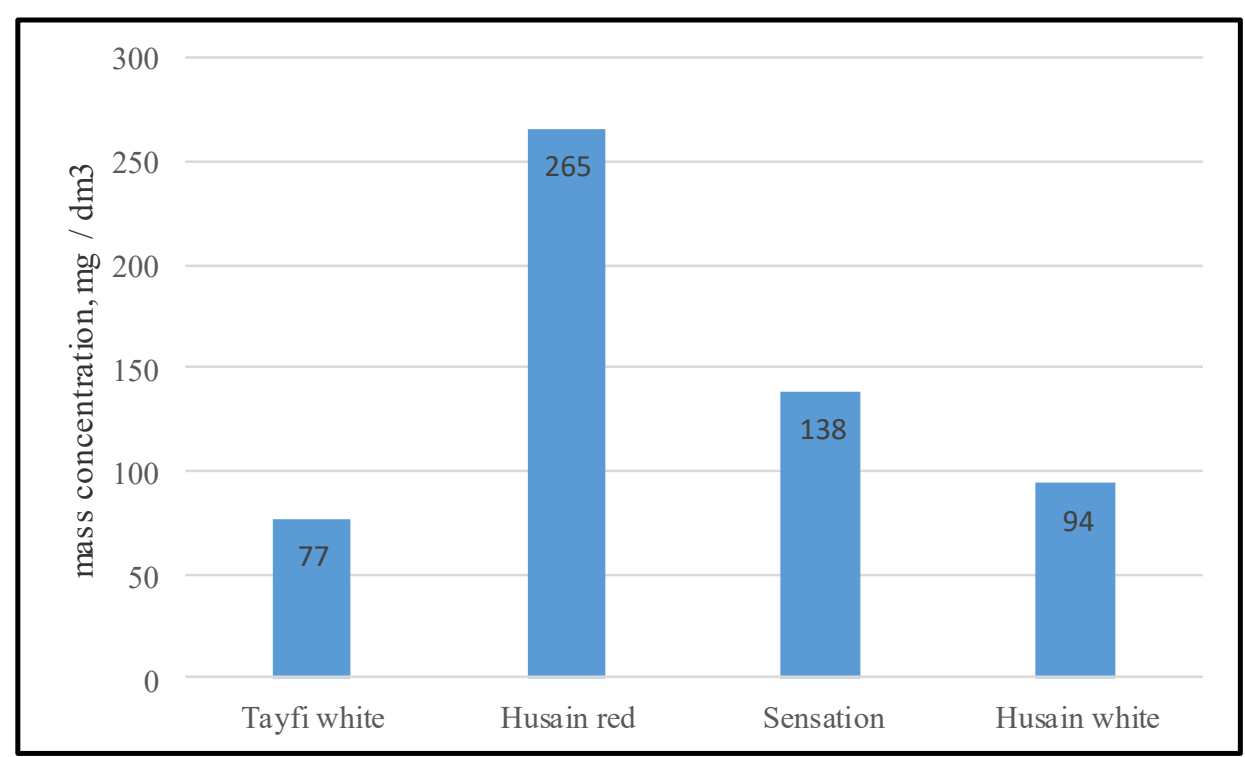

Figure 2. Mass concentration of essential amino acids after pasteurization in direct-pressed juices from grapes of promising varieties

The largest amount of essential amino acids was distinguished by a sample of juice from The Husain red variety - $265 \mathrm{mg} / \mathrm{dm}^{3}$, it had a high content of such amino acids as methionine $\left(130.2 \mathrm{mg} / \mathrm{dm}^{3}\right)$, threonine $(69.0$ $\left.\mathrm{mg} / \mathrm{dm}^{3}\right)$ and tryptophan $\left(45.7 \mathrm{mg} / \mathrm{dm}^{3}\right)$. 
The maximum content of $\beta$-phenylalanine was found in the juice variant from the Husain red grape variety- $9.0 \mathrm{mg} / \mathrm{dm}^{3}$. The maximum valine content of $28.8 \mathrm{mg} / \mathrm{dm}^{3}$ was found in the juice variant of the Sensation variety. The lowest mass concentrations of almost all essential amino acids were recorded in samples of juices from white Taifi white grape varieties $\left(77 \mathrm{mg} / \mathrm{dm}^{3}\right)$. In terms of the amount of interchangeable amino acids, the juice from the Sensation grape (1358 $\mathrm{mg} / \mathrm{dm}^{3}$ ) was in the first place among all juice types (figure 3 ).

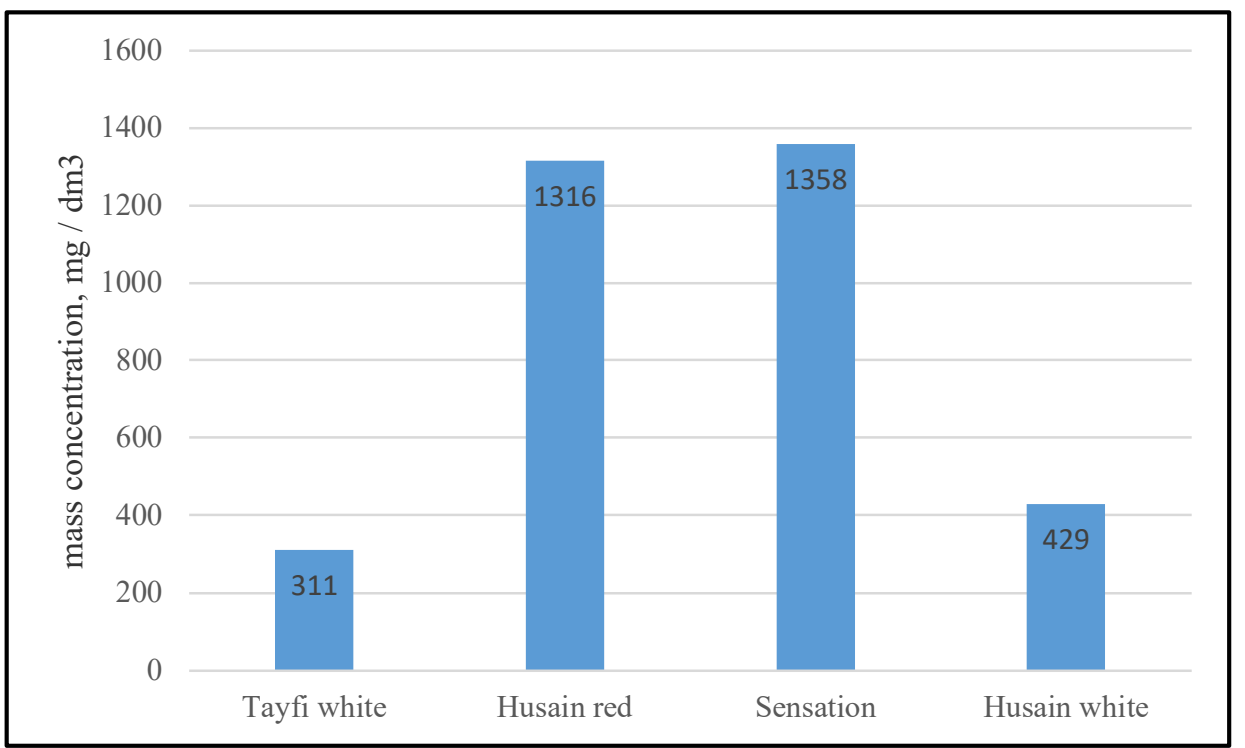

Figure 3. Mass concentration of interchangeable amino acids after pasteurization in direct-pressed juices from grapes of promising varieties

The mass concentration of Proline ranged from 236 (Typhoid) to $1280 \mathrm{mg} / \mathrm{dm}^{3}$ (Sensation) (table 3). Tyrosine $\left(28.1 \mathrm{mg} / \mathrm{dm}^{3}\right)$ was detected in juice variants from Husain red varieties.

As a result of research, it was found that the mass concentration of all amino acids after pasteurization in all samples was 1.5-2 times lower than in the red ones. It should be noted that the concentration of amino acids after pasteurization was more than $1500 \mathrm{mg} / \mathrm{dm}^{3}$ in the juices of the Sensation varieties, which is a fairly high indicator from the point of view of the biological value of the product.

\section{Conclusion}

In conclusion, from the analyzed prospective grape varieties, the juices obtained from the Sensation and Husain red varieties had the highest supply of free amino acids. In this case, the most attractive appearance, good taste, expressed by high organoleptic characteristics, had samples from the Sensation variety. All studied promising grape varieties can be used to produce high-quality grape juices. Given the totality of the data of organoleptic and chemical analysis of experimental samples, we recommended the varieties Sensation and Husain red for the production of juices with a high level of biological value.

\section{REFERENCES}

1. Durnev A.D., Oganesyants L. A., Lisitsyn A. B. Functional food products // Storage and processing of agricultural raw materials. - 2007. - no. 9. - P. 15-22. [in Russian]

2. Faradzheva E. D. et al. Soft drink of functional purpose // Beer and beverages. - 2010. - no. 1.- P. 32-37. [in Russian]

3. Sosyura E. A. and others. Extracts from plant raw materials in the technology of functional drinks. Vestnik agro-industrial complex of Stavropol. - 2013. - no. 2. - P. 41-44. [in Russian]

4. Sosyura E. A. and others. feijoa and BlackBerry Fruits-raw materials for the production of functional beverages // Beer and beverages. - 2013. no. 1.- P.19-22. [in Russian]

5. Sosyura E. A., Burtsev B. V., Guguchkina T. I. functional Drink based on grape juice // Vestnik agroindustrial complex of Stavropol. - 2011. - no. 4. P. 18-21. [in Russian]

6. Danina M. M., Radionova I. E. Methods of research of soft drinks and mineral waters: Studies.method. stipend. SPb.: ITMO University, 2016. -48 p. [in Russian]

7. M-04-38-2009: Method of measuring the mass fraction of amino acids by capillary electrophoresis using the capillary electrophoresis system "Drops". - S-Pb.: Lumex LLC, 2009.- 36 p. [in Russian]

8. Zhirova, V.V. amino Acid composition of clarified grape juices / V. V. Zhirova, O. P. Presnyakova // Beer and beverages. - 2004. - No. 5. - P. 46. [in Russian] 